8 Shetty PS, Jung RT, James WPT, Barrand MA, Callingham BA. Postprandial thermogenesis in obesity. Clin Sci 1981;60:519-25.

9 Golay A, Schutz Y, Meyer HU, et al. Glucose-induced thermogenesis in nondiabetic and diabetic obese subjects. Diabetes 1982;31:1023-8.

10 Swaminathan R, King RFGJ, Holmfield J, Siwek RA, Baker M, Wales JK. Thermic effect of feeding carbohydrate, fat, protein and mixed meal in lean and obese subjects. Am $\mathcal{f}$ Clin Nutr 1985;42:117-81.

11 Pittet PH, Chappuis K, Acheson F, de Techtermann F, Jequier E. Thermic effect of glucose in obese subjects studied by direct and indirect calorimetry. Brf Nutr 1976;35:281-92.

12 Ravussin E, Bogardus C, Schwartz RS, et al. Thermic effect of infused glucose and insulin in man: decreased response with increased insulin resistance in obesity and noninsulin dependent diabetes mellitus. F Clin Invest 1983;172:893-902.

13 De Luise M, Blackburn GL, Flier JS. Reduced activity of the red-cell sodium-potassium pump in human obesity. $N$ Engl f Med 1980;303:1017-22.

14 Klimes I, Nagulesparan M, Unger RH, Aronoff SL, Mott DM. Reduced $\mathrm{Na}^{+}, \mathrm{K}^{+}$ATPase activity in intact red cells and isolated membranes from obese man. $\mathcal{J}$ Clin Endocrinol Metab 1982;54:721-4.

15 Sowers JR, Whitfield LA, Beck FWJ, et al. Role of enhanced sympathetic nervous system activity and reduced $\mathrm{Na}^{+}, \mathrm{K}^{+}$-dependent adenosine triphosphatase activity in maintenance of elevated blood pressuse in obesity: effects of weight loss. Clin Sci 1982;63(suppl 8):121-4s.

16 Mir MA, Charalambous BM, Morgan K, Evans PJ. Erythrocyte sodium-potassium-ATPase and sodium transport in obesity. $N$ Engl f Med 1981;305:1264-8.

17 Beutler E, Kuhl W, Sacks P. Sodium-potassium-ATPase activity is influenced by ethnic origin and not by obesity. $N$ Engl f Med 1983;309:756-60.

18 Pacini G, Finegood DT, Bergman RN. A minimal-model-based glucose clamp yielding insulin sensitivity independent of glycemia. Diabetes 1982;31:432-41.

$19 \mathrm{Ng} \mathrm{LL}$, Hockaday TDR. The leucocyte sodium pump in healthy and obese subjects: the association of insulin with its activity. Clin Endocrinol 1986;25:383-92.

20 Baron DN, Ahmed SA. Intracellular concentrations of water and of the principal electrolytes determined by analysis of isolated human leucocytes. Clin Sci 1969;37:205-19.

21 Hilton PJ, Patrick J. Sodium and potassium flux rates in normal human leucocytes in an artificia extracellular fluid. Clin Sci 1973;44:439-45.

22 Poston L, Jones RB, Hilton PJ. Sodium transport in polymorphonuclear leucocytes: effect of isolation by the Ficoll/Triosil method. Clin Sci 1982;62:563-4.

23 Morgan CR, Lazarow A. Immunoassay of insulin using a two-antibody system. Proc Soc Exp Biol Med 1962;110:29-32.

24 Shimizu S, Inoue K, Tani Y, Yamada H. Enzymatic microdetermination of serum free fatty acids. Anal Biochem 1979;98:341-5.

25 Charalambous BM, Webster DJT, Mir MA. Elevated skeletal muscle sodium-potassium-ATPase in human obesity. Clin Chim Acta 1984;141:189-95.

26 Bray GA, Kral JG, Bjorntorp P. Hepatic sodium-potassium-dependent ATPase in obesity. NEngl f Med 1981;304:1580-2.

27 Turaihi K, Dandona P, Baron DN. Increased Na-K ATPase in leucocytes of obese patients: effect of weight loss. Clin Sci 1986;70(suppl 13):52P.
28 Rosic NK, Standaert ML, Pollet RJ. The mechanism of insulin stimulation of $\left(\mathrm{Na}^{+}\right.$, $\mathrm{K}^{+}$)-ATPase transport activity in muscle. $\mathcal{F}$ Biol Chem 1985;260:6206-12.

29 Aalkjaer C, Heagerty AM, Parvin SD, Bell PRF, Bing RF, Swales JD. Cell membrane sodium transport: a correlation between human resistance vessels and leucocytes. Lancet 1986;i:649-51.

30 Naylor GJ, Dick DAT, Warrall EP, Dick EG, Dick P, Boardman L. Changes in erythrocyte sodium pump with age. Gerontology 1977;23:256-61.

31 Nair KS, Halliday D, Garrow JS. Thermic response to isoenergetic protein, carbohydrate and fat meals in lean and obese subjects. Clin Sci 1983;65:307-12.

32 Bradford RB, Jourdan MH. Relative importance of specific dynamic action in weight-reduction diets. Lancet 1973;ii:640-3.

33 Sharief NN, Macdonald I. Differences in dietary-induced thermogenesis with various carbohydrates in normal and overweight man. Am f Clin Nutr 1982;35:267-72.

34 Welle SL, Campbell RG. Normal thermic effect of glucose in obese women. Am $\mathcal{F}$ Clin Nutr 1983;37:87-92.

35 Felig P, Cunningham J, Levitt $M$, Hendler R, Nadel E. Energy expenditure in obesity in fasting and postprandial state. Am $\mathcal{F}$ Physiol 1983;244:E45-51.

36 Nair KS, Webster J, Garrow JS. Effect of impaired glucose tolerance and type II diabetes on resting metabolic rate and thermic response to a glucose meal in obese women. Metabolism 1986;35:640-4

37 Jequier E, Schutz Y. Long term measurements of energy expenditure in humans using a respiration chamber. Am $\mathcal{f}$ Clin Nutr 1983;38:989-98.

$38 \mathrm{Ng} \mathrm{LL}$, Hockaday TDR. The effect of oral glucose on the leucocyte sodium pump in normal and obese subjects. Clin Endocrinol (in press).

39 Clausen T, Kohn PG. The effect of insulin on the transport of sodium and potassium in rat soleus muscle. I Physiol 1977;265: 19-42.

40 Resh MD, Nemenoff RA, Guidotti G. Insulin stimulation of Na-K-ATPase dependent ${ }^{86} \mathrm{Rb}^{+}$ uptake in rat adipocytes. $\mathcal{F}$ Biol Chem 1980;255:10938-45.

41 Ravussin E, Acheson J, Vernet O, Danforth E, Jequier E. Evidence that insulin resistance is responsible for the decreased thermic effect of glucose in human obesity. $\mathcal{J}$ Clin Invest 1985;76:1268-73.

42 Modan M, Halkin H, Almog S, Lusky A, Eshkol A, Shefi M. Hyperinsulinemia-a link between hypertension, obesity and glucose intolerance. $\mathcal{I}$ Clin Invest 1985;75:809-17.

43 Blaustein MP. Sodium ions, calcium ions, blood pressure regulation, and hypertension: a reassessment and a hypothesis. Am f Physiol 1977;232:C165-73.

44 Reisin E, Abel R, Modan M, Silverberg DS, Eliahou HE, Modan B. Effect of weight loss without salt restriction on the reduction of blood pressure in overweight hypertensive patients. $N$ Englf Med 1978;298:1-6.

45 Conn JW. Hypertension, the potassium ion and impaired carbohydrate tolerance. $N$ Engl $\mathrm{F}$ Med 1965;273:1135-42.

46 James WPT, Davies HL, Bailes J, Dauncey MJ. Elevated metabolic rates in obesity. Lancet 1978;i:1122-5.

\begin{abstract}
The concentration of substrate expressed as hypoxanthine capable of reacting with xanthine oxidase to release superoxide free radicals $\left(\mathrm{O}_{2}^{-}\right)$was measured in control and Dupuytren's contracture palmar fascia. In Dupuytren's contracture palmar fascia the concentration of hypoxanthine was six times that of control and was greatest in "nodular" areas. Xanthine oxidase activity was also detected in Dupuytren's contracture palmar fascia.

These results suggest a greater potential for hypoxanthinexanthine oxidase generated oxygen free radical formation in Dupuytren's contracture than in control palmar fascia. Production of free radicals may be an important factor in the pathogenesis of Dupuytren's contracture. The benefit of allopurinol in the management of Dupuytren's contracture and other fibrotic conditions may thus be explained, as allopurinol binds to xanthine oxidase and prevents release of free radicals.

Nuffield Department of Orthopaedic Surgery, University of Oxford, Nuffield Orthopaedic Centre, Oxford OX3 7LD

G A C MURRELL, MB, BS, research fellow

M J O FRANCIS, MA, DPHIL, university lecturer in biochemistry

L BROMLEY, BSC, medical laboratory scientific officer

Correspondence to: Dr Murrell.
\end{abstract}

\section{Introduction}

Dupuytren's contracture affects the palmar fascia, which becomes thickened and shortened and may lead to disabling fixed flexion deformities of the fingers. The prevalence in white populations is between $4 \%$ and $6 \%$, rising to $20 \%$ in men over $65,{ }^{1}$ and is higher in diabetics, particularly when retinopathy is present, but lower in patients with rheumatoid arthritis. ${ }^{23}$

The cause is unknown but may include localised ischaemia of the palmar fascia. ${ }^{45}$ During ischaemia adenosine triphosphate is broken down, increasing the amount of the purine bases hypoxanthine and xanthine and converting xanthine dehydrogenase to xanthine oxidase $^{67}$ (fig 1). Xanthine oxidase, located in the endothelial cells of small vessels, ${ }^{8}$ catalyses the conversion of both hypoxanthine to xanthine and xanthine to uric acid. Both reactions produce superoxide free radicals $\left(\mathrm{O}_{2}^{-}\right)$and hydrogen peroxide $\left(\mathrm{H}_{2} \mathrm{O}_{2}\right)$. Superoxide free radicals, hydrogen peroxide, and their degradation products may damage various tissues and alter vascular permeability. ${ }^{9 \cdot 11}$ In animal studies allopurinol (a competitive inhibitor of xanthine oxidase) and free radical scavengers such as superoxide dismutase and catalase limited the damage associated with acute ischaemia. ${ }^{12}{ }^{13}$ Preliminary clinical results suggest that allopurinol may improve Dupuytren's contracture. ${ }^{14}$

To see whether free radicals might be important in the pathogenesis of Dupuytren's contracture we have measured the concentration of substrates able to react with exogenous xanthine oxidase to produce superoxide free radicals in Dupuytren's and control palmar fascia. These substrates are most likely to 
be hypoxanthine and xanthine; for clarity we express these as hypoxanthine concentrations.

The activity of xanthine oxidase was also measured in $\mathrm{Du}$ puytren's contracture tissue from six patients and compared with values previously found in other human tissues. Samples of normal palmar fascia from control patients were too small for assay of xanthine oxidase activity.

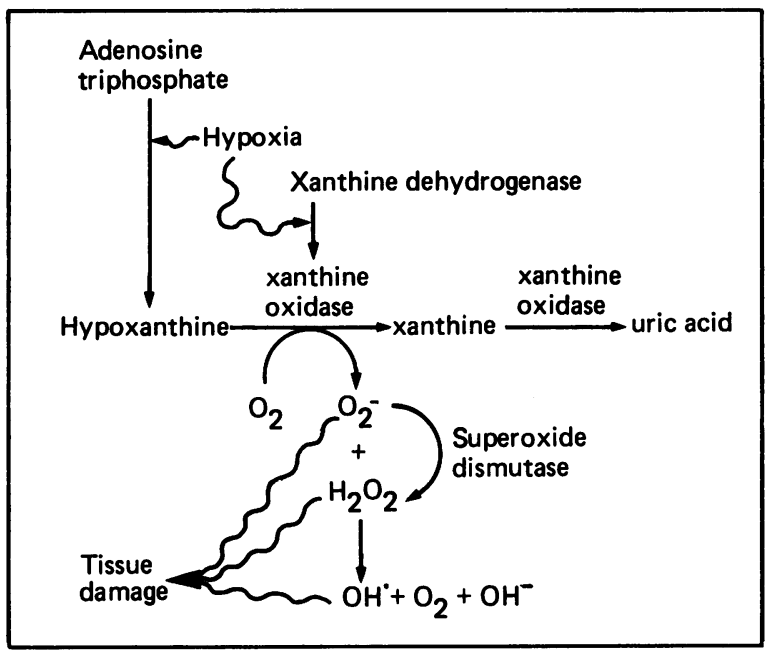

FIG 1-Mechanism of hypoxia induced free radical damage.

\section{Subjects and methods}

Palmar fascia was obtained from 10 patients (eight men, two women; age range 45-73) during fasciectomy for Dupuytren's contracture and from 10 patients having carpal tunnel release operations (five men, five women; age range 30-66). Both procedures were performed under tourniquet ischaemia. The effect of tourniquet ischaemia was examined in three patients by measuring the hypoxanthine concentrations in samples of skin subjected to 0-60 minutes of tourniquet ischaemia. All patients gave informed consent.

To assess the relation of cell density and histological appearance to hypoxanthine concentration in Dupuytren's contracture palmar fascia we dissected one large sample of Dupuytren's tissue into 10 pieces. Hypoxanthine concentrations were measured in each piece and representative segments fixed in formaldehyde, embedded in paraffin wax, sectioned, and stained with haematoxylin and eosin. Cell density was determined by using a graticule and $1 \mathrm{~mm}$ graduated slide.

Hypoxanthine assay-All samples were placed immediately in liquid nitrogen, stored at $-20^{\circ} \mathrm{C}$, and later carefully dissected, weighed, and

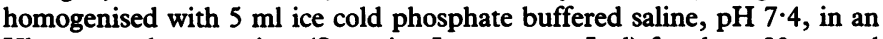
Ultraturrax homogeniser (Sartorius Instruments Ltd) for three 20 second periods and spun at $105000 \mathrm{~g}$ at $4^{\circ} \mathrm{C}$ for 30 minutes in a $T_{i} 40.1$ rotor (Beckman). The supernatant was freeze dried, heat denatured to remove any endogenous xanthine oxidase, reconstituted, and filtered before assay. The concentration of substrates able to release superoxide free radicals with the addition of exogenous xanthine oxidase was measured by the superoxide dismutase inhibitable reduction of cytochrome $c .{ }^{\text {s }}$ One millilitre of sample solution or hypoxanthine (Sigma) standard was mixed with cytochrome $c$ (Sigma; final concentration $50 \mu \mathrm{mol} / \mathrm{l}$ ) and phosphate buffered saline, $\mathrm{pH}$ $7 \cdot 4$, and equilibrated at $37^{\circ} \mathrm{C}$ for 10 minutes before the addition of $6 \mathrm{mU}$ xanthine oxidase (Sigma) to test samples. Final volume was $2 \mathrm{ml}$. The rate of cytochrome c reduction at $550 \mathrm{~nm}$ was recorded in a Gilford 2600 spectrophotometer, compared with a standard curve constructed with hypoxanthine as substrate, and the result expressed as $\mu \mathrm{mol}$ hypoxanthine/g wet weight of tissue. Each sample was analysed in triplicate.

Xanthine oxidase assay—Sterile operative samples were placed immediately in cold $\left(4^{\circ} \mathrm{C}\right)$ Dulbecco's modification of Eagle's medium (Flow Laboratories) containing $10 \%$ (vol/vol) fetal calf serum (Flow) with $550 \times 10^{6} \mathrm{U}$ benzylpenicillin and $275 \mathrm{mg}$ streptomycin/l. The tissue was chopped into $2 \mathrm{~mm}$ cubes and washed in phosphate buffered saline. One cube was placed in each $1.6 \mathrm{~cm}$ well of a 24 multiwell culture dish (Flow). One millilitre of phosphate buffered saline, $\mathrm{pH} 7 \cdot 4$, containing glucose (final concentration $2 \mathrm{mmol} / \mathrm{l}$ ), hypoxanthine (final concentration $100 \mu \mathrm{mol} / \mathrm{l}$ ), and cytochrome c (final concentration $50 \mu \mathrm{mol} / \mathrm{l}$ ), with allopurinol (Wellcome; final concentration $100 \mu \mathrm{mol} / \mathrm{l}$ ) and superoxide dismutase (Sigma; final concentration $60 \mathrm{mg} / \mathrm{l}$ ) where appropriate, was added to each well. Twelve wells were free of allopurinol (six with superoxide dismutase, six without) and 12 contained allopurinol (six with superoxide dismutase, six without). The culture plate was incubated at $37^{\circ} \mathrm{C}$ for 60 minutes with continuous agitation. All procedures were performed under sterile conditions. The reaction was stopped by adding $1 \mathrm{ml} 2 \mathrm{mM}$ N-ethylmaleimide (Sigma) and cytochrome $\mathrm{c}$ reduction measured. Superoxide release was calculated from the average difference in absorbance of the samples with and without superoxide dismutase. The difference in superoxide release between the samples with and without allopurinol was attributed to xanthine oxidase activity and calculated from a standard curve constructed with known concentrations of xanthine oxidase. Dry weight of each piece of tissue was adjusted to equivalent wet weight and the results expressed as $\mathrm{mU}$ xanthine oxidase activity/g wet weight of tissue.

Statistics-Mann-Whitney non-parametric $\mathrm{U}$ tests were used for all data.

\section{Results}

A sixfold increase in hypoxanthine concentration was found in Dupuytren's palmar fascia compared with control palmar fascia (mean 0.26 (SE 0.04$) \mu \mathrm{mol} / \mathrm{g}$ wet weight compared with $0.04(0.01) \mu \mathrm{mol} / \mathrm{g}$ wet weight); $\mathrm{n}=10$ for both groups; $\mathrm{p}<0.001$ ). In the single large piece of Dupuytren's tissue examined and sectioned the hypoxanthine concentration increased with cell density and was double the value in tissue classified as "nodular" compared with "cord" (mean 0.32 (SE 0.03) compared with $0.14(0.03) \mu \mathrm{mol} / \mathrm{g}$ wet weight; $\mathbf{p}<0.005$ (fig 2)). A $1-47 \%$ increase in hypoxanthine concentration was found in skin subjected to 60 minutes of tourniquet ischaemia.

The mean xanthine oxidase activity in Dupuytren's contracture tissue from six patients was 13 (SE 6.1) (range 1-41) $\mathrm{mU} / \mathrm{g}$ wet weight. This is higher than that found for lung and heart but less than that for intestine (table).

\section{Discussion}

We have detected higher concentrations of hypoxanthine in Dupuytren's contracture palmar fascia than in control palmar fascia. Longer tourniquet time for operative correction of

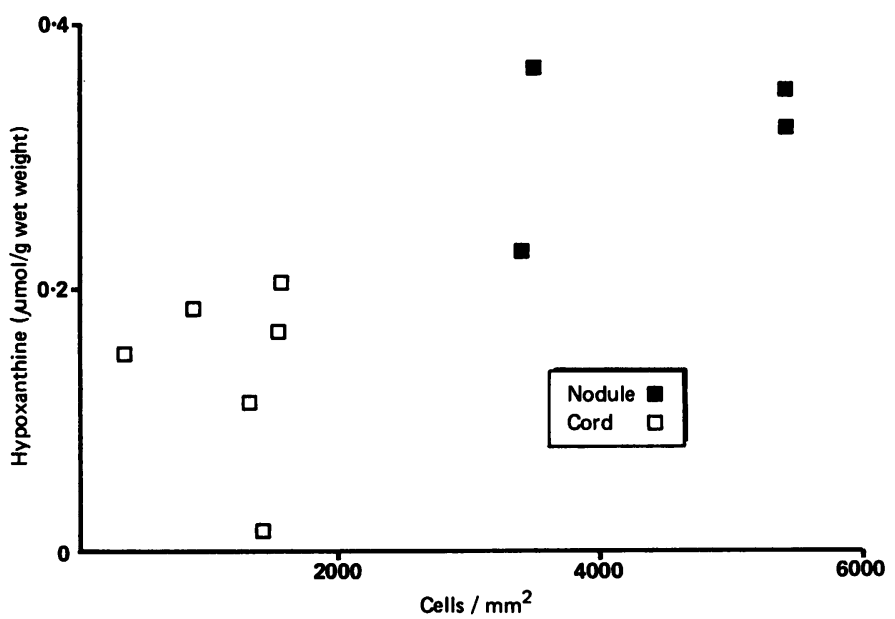

FIG 2-Histological appearance (cord or nodule) and cell density versus hypoxanthine concentration in single piece of Dupuytren's contracture palmar fascia.

Comparison of xanthine oxidase activities in different human tissues

\begin{tabular}{|c|c|c|}
\hline Tissue & $\begin{array}{l}\text { Xanthine oxidase } \\
\text { (mU/g wet weight) }\end{array}$ & Reference \\
\hline $\begin{array}{l}\text { Lung } \\
\text { Heart } \\
\text { Liver } \\
\text { Intestine } \\
\text { Spleen } \\
\text { Kidney } \\
\text { Dupuytren's palmar fascia }\end{array}$ & $\begin{array}{l}0-7 \\
0 \\
10-123 \\
29-56 \\
2-44 \\
3-53 \\
1-41\end{array}$ & $\begin{array}{l}\text { Ramboer, }{ }^{19} \text { Krenitsky et a }{ }^{20} \\
\text { Ramboer, }{ }^{19} \text { Krenitsky et a }{ }^{20} \\
\text { Ramboer, }{ }^{19} \text { Krenitsky et a a }{ }^{20} \\
\text { Ramboer, }{ }^{19} \text { Krenitsky et a } 2^{20} \\
\text { Ramboer, }{ }^{19} \text { Krenitsky et a } 2^{20} \\
\text { Ramboer, }{ }^{19} \mathrm{Krenitsky} \text { et a } \text { l }^{20} \\
\text { Present study }\end{array}$ \\
\hline
\end{tabular}


Dupuytren's contracture versus carpal tunnel release may account for less than one tenth of the $600 \%$ increase. It is also relevant that hypoxanthine concentrations were higher in the cellular areas of Dupuytren's contracture tissue as it is from these areas that the proliferative process is thought to arise.

Xanthine oxidase activity was also found in Dupuytren's contracture palmar fascia, establishing a potential for oxygen free radical production by the xanthine oxidase-hypoxanthine reaction.

These results support our hypothesis that in Dupuytren's contracture palmar fascia high concentrations of hypoxanthine may react with xanthine oxidase located in the endothelial cells ${ }^{8}$ of narrowed microvessels ${ }^{4}$ to release oxygen free radicals. ${ }^{14}$ These free radicals may then damage the perivascular connective tissue and induce a reparative response by surrounding fibroblasts. Alternatively free radicals may directly stimulate proliferation of fibroblasts. We have added free radicals to fibroblasts cultured from Dupuytren's contracture palmar fascia and found, like others, ${ }^{1011}$ that high concentrations of free radicals are toxic, but that in contrast lower concentrations stimulate fibroblast proliferation. ${ }^{16}$ The proliferating fibroblasts may then be responsible for the increase in type III collagen seen in Dupuytren's contracture and the early stages of normal wound healing. ${ }^{17} 18$

There is increasing evidence to suggest that acute ischaemic damage is mediated by oxygen free radicals. ${ }^{12}{ }^{13}$ We propose that free radical damage may also occur in chronic ischaemic settings, leading to fibroblast proliferation and localised fibrosis. Our findings also suggest that allopurinol by binding to xanthine oxidase and hence preventing free radical release may be useful in both chronic and acute ischaemia and in Dupuytren's contracture. ${ }^{14}$

We are indebted to the patients and surgeons of the Nuffield Orthopaedic Centre for the tissue specimens and to Dr James Crabbe and Dr Roger Smith for valuable advice. GACM is supported by the Rhodes Trust.

\section{References}

1 Evans RA. The aetiology of Dupuytren's disease. Brf Hosp Med 1986;36: 198-9.

2 Larkin JG, Frier BM. Limited joint mobility and Dupuytren's contracture in diabetic, hypertensive, and normal populations. $B r M e d \mathcal{J}$ 1986;292:1494.

3 Arafa M, Steingold RF, Noble J. The incidence of Dupuytren's disease in patients with rheumatoid arthritis. 7 Hand Surg 1984;9B:165-6.

4 Kischer CW, Speer DP. Microvascular changes in Dupuytren's contracture. $\mathcal{F}$ Hand Surg 1984;9A:58-62.

5 Rabinowitz JL, Ostermann JR, Bora FW, Staeffer J. Lipid composition and de novo lipid biosynthesis of human palmar fat in Dupuytren's disease. Lipids 1983;5:371-3.

6 Jones CE, Crowell JW, Smith EE. Significance of increased blood uric acid following extensive hemorrhage. Am F Physiol 1968;214:1374-7.

7 Stirpe F, Della Corte E. The regulation of rat liver xanthine oxidase. 7 Biol Chem 1969;244: 3855-63.

8 Jarasche ED, Grund C, Bruder G, Heid HW, Keenan TW, Franke WW. Localization of xanthine oxidase in mammary-gland epithelium and capillary endothelium. Cell 1981;25:67-82.

9 Del Maestro RF, Bjork J, Arfors KE. Increase in microvascular permeability induced by enzymatically generated free radicals. Microvasc Res 1981;22:239-70.

10 Freeman BA, Rosen GM, Barber MJ. Superoxide perturbation of the organization of vascular endothelial cell membranes. F Biol Chem 1986;261:6590-3.

11 Simon RH, Scoggin $\mathrm{CH}$, Patterson D. Hydrogen peroxide causes fatal injury to human fibroblasts exposed to oxygen radicals. $\mathcal{F}$ Biol Chem 1981;256:7181-6.

12 Granger DN, Rutili G, McCord JM. Superoxide radicals in feline intestinal ischemia. Gastroenterology 1981;81:22-9.

13 Saez JC, Cifuentes F, Ward PH, Gunther B, Vivaldi E. Tourniquet shock in rats: effect of allopurinol on biochemical changes of the gastrocnemius muscle subjected to ischaemia followed by reperfusion. Biochemical Medicine and Metabolic Biology 1986;35:199-209.

14 Murrell GAC, Murrell TGC, Pilowsky E. A hypothesis for the resolution of Dupuytren's contracture with allopurinol. Speculations in Science and Technology 1987;10:107-12.

15 Weening RS, Wever R, Roos D. Quantitative aspects of the production of superoxide radicals by phagocytizing human granulocytes. F Lab Clin Med 1986;85:245-52.

16 Murrell GAC, Francis MJO, Bromley L. Stimulation of fibroblast proliferation by oxygen free radicals. In: Maddison P, ed. Strangeways Research Laboratory 75th anniversary symposium.

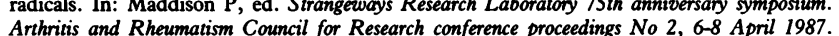
London: ARCR, 1987:4.4:117-22.

17 Hayakawa T, Hashimoto Y, Myokei Y, Aoyama H, Izawa Y. Changes in type of collagen during the development of human post-burn hypertrophic scars. Clin Chim Acta 1979;93:119-25.

18 Brickley-Parsons D, Glimcher MJ, Smith RJ, Albin R, Adams J. Biochemical changes in the collagen of the palmar fascia in patients with Dupuytren's disease. $\mathcal{f}$ Bone foint Surg 1981;63A:787-97.

19 Ramboer CRH. A sensitive and nonradioactive assay for serum and tissue xanthine oxidase. f Lab Clin Med 1969;74:828-35.

20 Krenitsky TA, Tuttle JV, Cattau EL, Wang P. A comparison of the distribution and electron acceptor specificities of xanthine oxidase and aldehyde oxidase. Comp Biochem Physiol 1974;49B:687-703.

(Accepted 25 September 1987)

\title{
Treatment of Niemann-Pick disease type B by allogeneic bone marrow transplantation
}

\author{
A VELLODI, J R HOBBS, N M O'DONNELL， B S COULTER， K HUGH-JONES
}

\begin{abstract}
Allogenic bone marrow transplantation was carried out on a 3 year old girl with Niemann-Pick disease type B. Successful engraftment was achieved, and nine months after the procedure there was definite clearing of the sphingomyelin from the liver and pronounced clearing from the bone marrow.
\end{abstract}

Bone Marrow Transplant Unit, Westminster Children's Hospital, London SW1

A VELLODI, MRCP, junior lecturer

J R HOBBS, FRCPATH, FRCP, professor and director of unit

K HUGH-JONES, MD, FRCP, senior consultant paediatrician

Department of Histopathology, Westminster Hospital, London SW1

N M O'DONNELL, MB, BAO, registrar

Alder Hey Children's Hospital, Liverpool L12 2AP, and Liverpool School of Tropical Medicine

B S COULTER, MD, FRCPI, honorary consultant paediatrician, senior lecturer in tropical paediatrics

Correspondence to: Dr Vellodi.
Any patient with Niemann-Pick disease type B complicated by early or severe hepatic impairment should be considered for bone marrow transplantation.

\section{Introduction}

Niemann-Pick disease type $B$ is a lysosomal storage disorder characterised by a deficiency of sphingomyelinase resulting in the accumulation of sphingomyelin in tissues, particularly the bone marrow, liver, spleen, and lungs, but with no discernible neurological abnormality. ${ }^{1}$

We report a case of Niemann-Pick disease type B treated by displacement bone marrow transplantation.

\section{Case report}

An 8 month old white girl was diagnosed as having Niemann-Pick disease after investigations for an enlarged liver and spleen. The diagnosis was confirmed by finding a very low level of sphingomyelinase activity in her leucocytes. The absence of any obvious neurological impairment placed her 